\title{
A Risk Assessment of Factors for the Presence of Angiodysplasias During Endoscopy and Factors Contributing to Symptomatic Bleeding and Rebleeds
}

\author{
K. V. Grooteman ${ }^{1}$ D $\cdot$ G. Holleran ${ }^{2}$ - M. Matheeuwsen ${ }^{1}$ - E. J. M. van Geenen ${ }^{1}$ - D. McNamara ${ }^{2}$. J. P. H. Drenth ${ }^{1}$
}

Received: 6 July 2017 / Accepted: 23 May 2019 / Published online: 12 June 2019

(C) The Author(s) 2019

\begin{abstract}
Background Few studies have assessed factors associated with angiodysplasias during endoscopy or factors associated with symptomatic disease.

Aims To evaluate risk factors for the presence of and contribution to symptomatic disease in patients with angiodysplasias. Methods We performed a systematic MEDLINE, EMBASE and Cochrane Library search according to the PRISMA guidelines for studies assessing risk factors involved in angiodysplasias detected during endoscopy and factors that lead to anemia or overt bleeding. Study quality was assessed with the Newcastle-Ottawa scale. A risk assessment was performed by selecting risk factors identified by two independent studies and/or by a large effect size.

Results Twenty-three studies involving 92,634 participants were included. The overall quality of the evidence was moderate. Risk factors for the diagnosis of angiodysplasias during endoscopy confirmed by at least two studies were increasing age (OR 1.09 per year, 95\% CI 1.04-1.1), chronic kidney disease (OR 4.5, 95\% CI 1.9-10.5) and cardiovascular disease (2.9, 95\% CI 1.4-6.2). The risk of rebleeds was higher in the presence of multiple lesions (OR 4.2, 95\% CI 1.1-16.2 and 3.8, 95\% CI 1.3-11.3 and 8.6, 95\% CI 1.4-52.6), liver cirrhosis (OR 4.0, 95\% 1.1-15.0) and prothrombin time <30\% (OR 4.2, 95\% 1.1-15.4) with a moderate effect size. Multiple comorbidities were associated with an increased in-hospital mortality (OR 2.29, 95\% CI 1.2-4.3). Conclusions This systematic review identified age, chronic kidney disease and cardiovascular disease as the most important risk factors for the diagnosis of angiodysplasias during endoscopy. Multiple lesions increase the risk of recurrent bleeding.
\end{abstract}

Keywords Angiodysplasia/angioectasia - Gastrointestinal bleeding · Systematic review · Risk factors · Disease severity · Prognosis

Electronic supplementary material The online version of this article (https://doi.org/10.1007/s10620-019-05683-7) contains supplementary material, which is available to authorized users.

K. V. Grooteman

karina.grooteman@radboudumc.nl

G. Holleran

grainneholleran@gmail.com

M. Matheeuwsen

matheeuwsen_1@ @hotmail.com

E. J. M. van Geenen

erwin.vangeenen@radboudumc.nl

D. McNamara

mcnamad@tcd.ie

\section{Introduction}

Angiodysplasias account for up to $5 \%$ of all causes of gastrointestinal bleeding and are probably responsible for $60 \%$ of cases of small bowel bleeding [1]. They are a common cause of gastrointestinal bleeding in the elderly [2]. Presentation

\section{J. P. H. Drenth}

joostphdrenth@cs.com

Department of Gastroenterology and Hepatology, Radboud University Medical Center, PO Box 9101, 6500 HB Nijmegen, The Netherlands

2 Department of Clinical Medicine, Trinity College Dublin, Tallaght Hospital, Dublin 24, Ireland 
includes all aspects of iron-deficiency anemia and gastrointestinal bleeding. The clinical spectrum may range from the absence of symptoms to the refractory anemia with transfusion dependency and frequent hospitalizations.

Angiodysplasias are thought to arise from chronic lowgrade intermittent obstruction of submucosal veins leading to capillary congestion and failure of the pre-capillary sphincters [3]. This results in dilated veins which are prone to bleeding (Fig. 1). Angiogenic factors [4] such as vascular endothelial growth factor and Angiopoietin-2 and -1 may play a role [5]. Thalidomide and somatostatin analogs inhibit angiogenesis and may serve as treatment for gastrointestinal angiodysplasias [6].

In addition to an increasing age, there are a number of predisposing conditions such as Von Willebrand disease, aortic stenosis (Heyde's syndrome) and chronic kidney disease [11-14]. The introduction of the colorectal

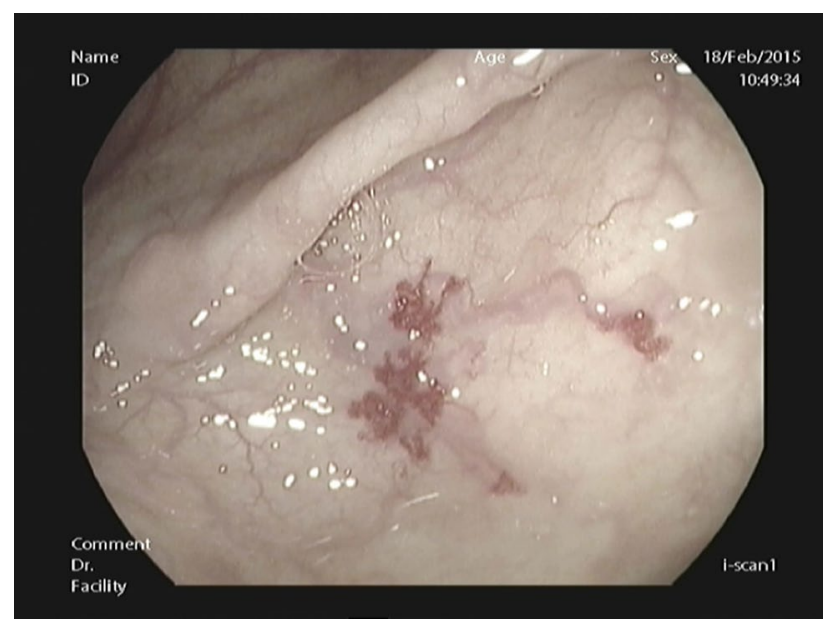

Fig. 1 Angiodysplasia in the colon. Legend: the differential diagnosis of angiodysplasias consists of other vascular malformations. They are caused by different mechanisms than angiodysplasias, leading to different treatment strategies. Portal hypertensive gastropathy can only develop in the presence of increased portal pressure. Histological (submucosal) biopsies show dilation and congested, tortuous submucosal venules [7]. This also differentiates from gastric antral vascular ectasias where biopsies show the presence of fibrin thrombi in dilated capillaries and fibromuscular proliferation in the lamina propria. As the name suggests, these two vascular diseases are limited to stomach involvement. Radiation-induced telangiectasias are caused by the toxicity of radiotherapy. The found telangiectasias are often multiple, and involvement is delimited to the area that received radiation [8]. Eosinophilic infiltrates, epithelial atypia, fibrosis and capillary telangectasia can be found in histological specimens. As last, a dieulafoy lesion is a submucosal artery that erodes the overlying epithelium and is of prominent caliber due to abnormal branching without the presence of an ulcer. These lesions might not be seen during endoscopy in case they are not actively bleeding [9]. The congenital inherited diseases hereditary hemorrhagic teleangectasia, blue rubber bleb nevus syndrome and Klippel-Trénaunay syndrome can present with angiodysplastic features during endoscopy; however, these disorders often become symptomatic at a young age, and the vascular malformations are present in multiple organs [10] cancer screening program has led to a major increase in number of endoscopies performed in the population older than 55 years with a positive immunological fecal occult blood test [15]. This will probably contribute to a further increase in diagnosis of (asymptomatic) angiodysplasias. Collectively, this has led to the increase in angiodysplasia related hospitalizations from 0.9 (1996) to 2.6 (2005) per 100.000 person-years [16].

Little is known about the nature of risk factors that contribute to the development of angiodysplasias. Better understanding of these factors may help to predict which patient is at risk to develop symptoms from angiodysplasias. High risk may warrant preemptive therapeutic argon plasma coagulation at time of diagnosis, close follow-up and/or initiation of angiogenesis inhibitors in an earlier stage. Secondly, elimination of those triggers that cause bleeding may serve as a preferential strategy in patients with recurrent angiodysplasia bleeding or chronic transfusion dependency. Finally, there is a wide variety of disease burden in patients with angiodysplasias [17]. The consequence is that most angiodysplasia studies are heterogeneous by nature and that extrapolation of results is difficult [18-23]. We used a systematic review in order to provide a comprehensive overview of risk factors associated with different disease stages: angiodysplasias found during endoscopy, angiodysplasias that lead to anemia or overt bleeding and factors of influence on recurrent bleeding and mortality.

\section{Methods}

This study is in accordance with the Preferred Reporting Items for Systematic Reviews and Meta-Analyses (PRISMA) guidelines [24].

\section{Literature Search}

A systematic search was conducted with the aid of an expert librarian. We retrieved relevant publications from MEDLINE and Cochrane Library up to August 2018 and for the EMBASE database up to August 2016. We used search terms for the determinant 'gastrointestinal angiodysplasia' with synonyms for the outcome 'risk factor' (see supplementary file, search strategy). Titles, abstracts and subsequent full-text articles were independently screened by two authors (K.V.G. and M.M.) based on predefined selection criteria. Disagreement on eligibility was resolved through consensus. The search was completed by hand-searching the references of the selected articles, related reviews, meta-analyses and guidelines. 


\section{Inclusion and Exclusion Criteria}

We selected published articles that reported on studies assessing risk factors for angiodysplasias detected during endoscopy or that investigated factors that contribute to symptomatic angiodysplasia bleeding, or more severe disease including rebleeds or mortality due to gastrointestinal angiodysplasias bleeding. Symptomatic disease is defined as angiodysplasias that cause anemia or overt bleeding. We excluded the following type of studies: case reports, case series $<40$ patients, reviews, editorials, opinion papers, animal or children studies, nonclinical studies. The search was not time limited. Non-Dutch and non-English language articles were excluded. Finally, studies that included vascular malformations other than angiodysplasias of the GI system, such as portal hypertensive gastropathy, radiation telangiectasia, hereditary hemorrhagic telangiectasia and gastric antral vascular ectasia, were excluded. The diagnosis of angiodysplasia had to be made through endoscopy, which also includes wireless video capsule endoscopy, or identification by International Statistical Classification of Diseases (ICD)-codes (ICD-9 537.82, 537.83, 569.84 and ICD-10 K55.20, K55.21).

\section{Data Extraction}

The following study characteristics were extracted from each study in a standardized manner: year of publication, country of origin, study design and population, sample size and type of control group. The preferred outcomes were odd's ratios (OR) or hazard ratios (HR) with their 95\% confidence intervals (95\%-CI). If not available the reported outcomes such as prevalence were drawn from the original manuscript.

\section{Quality Assessment}

Eligible articles were critically appraised for relevance and internal validity. The quality of each study was assessed with the Newcastle-Ottawa Quality Assessment Scale for nonrandomized studies [25]. The following domains of bias were addressed: representativeness of the cases, adequate selection, comparability, outcome assessment and follow-up. Each of the eight items can be scored as adequate using an $\mathrm{X}$, except for the domain comparability which is given two $\mathrm{Xs}$. The overall rating of the risk of bias is scored as low (7-9 X), moderate (4-6 X) or high (0-3 X). Publication bias was assessed graphically with a funnel plot.

\section{Statistical Analysis and Risk Assessment}

Due to variations in study population, methodologies and measurements between studies, a formal meta-analysis was deemed inappropriate here. A 95\% confidence interval (95\% CI) not including 0 or a two-sided tested $p$ value $\leq 0.05$ was considered statistically significant.

The risk assessment identifies important risk factors based on two criteria: strength of evidence and effect size. When risk factors were identified by at least two independent studies, those factors were identified as more important due to the increased strength in evidence [26] A risk factor identified by one study with a moderate (OR 3.5-6.6) or large effect size $(\mathrm{OR} \geq 6.7)$ was ought to be important as well based on it is effect size [27].

\section{Results}

The original search yields 1322 citations, after applying the in- and exclusion criteria for study selection, and 23 studies were included for qualitative synthesis (see Fig. 2: flow diagram). Most studies were excluded because they did not match our study aim (e.g., these studies focused on treatment efficacy or diagnostic modalities) or because they were case reports or conference abstracts. Two additional studies that fit inclusion criteria were discovered through checking the references of the included studies. Within the set of 23 reviewed studies included in our systematic review, 13 ( $n=1429$ patients) were on risk factors associated with the presence of angiodysplasia during endoscopy, two dealt with triggers for symptomatic angiodysplasias ( $n=4594$ patient) and eight assessed risk factors for rebleeds and mortality ( $n=86,611$ patients).

\section{Study Assessment}

Risk of bias was introduced at different levels and was mostly dependent on the design of the study (supplementary file, Table 1). Funnel plot showed similar estimates (OR) with similar sample sizes, which lead to asymmetry and could be an indication for a risk of publication bias (supplementary file, figure 2). No statistical tests were performed to detect bias, because of the large betweenstudy heterogeneity. Overall, the risk of bias was judged as high in six studies, moderate in 17 studies and low in one study. The quality of evidence was too low to perform a meta-analysis.

\section{Risk Factors for Angiodysplasias Found During Endoscopy}

Thirteen studies assessed risk factors for the presence of angiodysplasias detected during endoscopy (Table 1,2) [15, 28-39, 41]. Nine studies (Table 1) assessed risk factors for the presence of angiodysplasias in patients with overt or occult gastrointestinal bleeding compared to patients without 


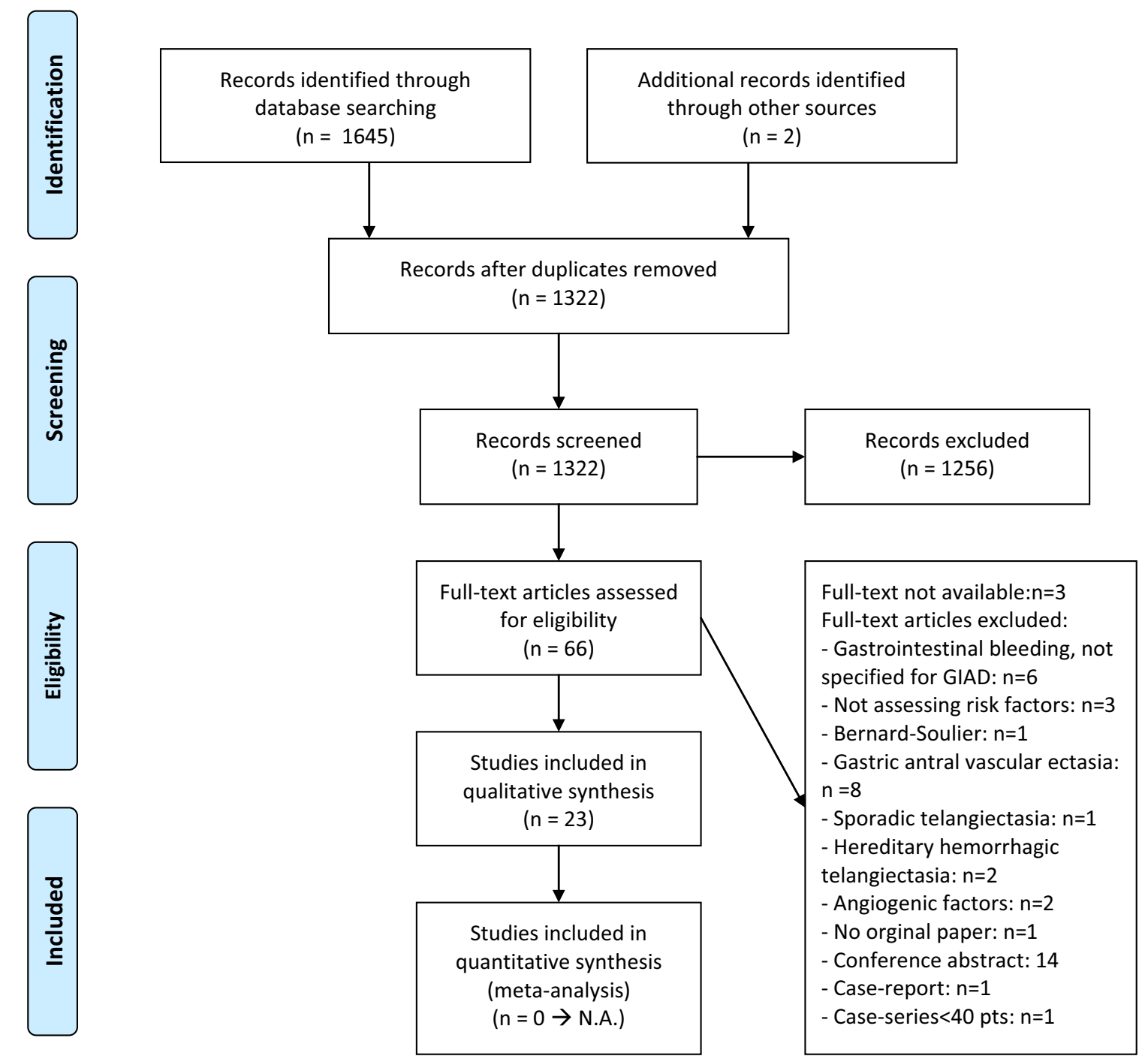

Fig. 2 Flow diagram of the search results

angiodysplasias and bleeding. Independent risk factors that were confirmed in two or more studies were increasing age (OR 1.09 per year, 95\% CI 1.04-1.1), chronic kidney disease (OR 4.5, 95\% CI 1.9-10.5) and cardiovascular disease (OR 2.9, 95\% CI 1.4-6.2). The association between liver cirrhosis and the presence of angiodysplasias in overt or occult bleeding patients had a moderate effect size (OR 4.8, 95\% CI 1.8-14.5).

In Table 2, studies are shown that assess the presence of symptomatic angiodysplasias compared to patients without gastrointestinal bleeding. Chronic kidney disease was associated with two studies with bleeding angiodysplasias (OR 4.5 and 21.0). The association between the following conditions and bleeding angiodysplasias had a moderate to large effect size: valvular heart disease (OR 18.8, 95\% CI 2.4-149.6), previous venous thromboembolism (OR 6.4, 95\% CI 1.3-31.3),
Warfarin use (OR 5.5, 95\% CI 1.1-27.5), proton pump inhibitor use (OR 5.4, 95\% CI 2.7-10.7), congestive heart failure (OR 4.5, 95\% CI 1.2-17.9), arrhythmias (OR 4.4, 95\% CI 1.7-11.2) and ischemic heart disease (OR 4.3, 95\% CI 1.9-9.8).

In studies focused one specific patient category, the following conditions are risk factors for angiodysplasias: LVADs, mitral valve regurgitation [34] and systemic sclerosis and calcinosis, Raynaud's phenomenon, esophageal dysmotility, sclerodactyly and telangiectasia (CREST) syndrome (6.3\% of GI bleeding due to AD) [35, 38]. Hypertension was identified as a risk factor for small bowel disease (OR 2.8, 95\% CI 1.5-5.4) [29], although its presence may confer protection against bleeding in patients with LVADs (OR 0.2, 95\% CI $0.1-0.97)$ [33]. 
Table 1 Studies assessing factors associated with the presence of gastrointestinal angiodysplasias (GIAD) compared to no angiodysplasias in patients with overt or occult bleeding

\begin{tabular}{|c|c|c|c|c|c|c|c|}
\hline \multirow{2}{*}{$\begin{array}{l}\text { Author Country, } \\
\text { year }\end{array}$} & \multirow[t]{2}{*}{ Study type } & \multirow{2}{*}{$\begin{array}{l}\text { No. of } \\
\text { comparison } \\
\text { patients }\end{array}$} & \multirow{2}{*}{$\begin{array}{l}\text { No. of } \\
\text { GIAD } \\
\text { pts }\end{array}$} & \multirow{2}{*}{$\begin{array}{l}\text { Endoscopy method } \\
\text { and indication }\end{array}$} & \multirow[t]{2}{*}{ Study population } & \multicolumn{2}{|l|}{ Outcomes } \\
\hline & & & & & & $\begin{array}{l}\text { Significant risk } \\
\text { factors }\end{array}$ & $\begin{array}{l}\text { EffectOR }(95 \% \text {-CI }) / t \\
\text { test }\end{array}$ \\
\hline \multirow{2}{*}{$\begin{array}{l}\text { Igawa et al. Japan, } \\
2015 \text { [28] }\end{array}$} & \multirow[t]{2}{*}{$\mathrm{CC}$} & \multirow[t]{2}{*}{97} & \multirow[t]{2}{*}{64} & \multirow{2}{*}{$\begin{array}{l}\text { SBCE and balloon } \\
\text { endoscopy for } \\
\text { OGIB }\end{array}$} & \multirow[t]{2}{*}{ Small bowel GIAD } & Liver cirrhosis & $4.8(1.8-14.5)$ \\
\hline & & & & & & $\begin{array}{l}\text { Cardiovascular } \\
\text { disease }\end{array}$ & $2.9(1.4-6.2)$ \\
\hline $\begin{array}{l}\text { Macdonald et al. } \\
\text { UK, } 2010 \text { [30] }\end{array}$ & $\mathrm{CC}$ & 91 & 46 & SBCE, $72 \%$ OGIB & GIAD & Increasing age & $1.09(1.04-1.1)$ \\
\hline \multirow[t]{2}{*}{$\begin{array}{l}\text { Chak et al. USA, } \\
1998 \text { [31] }\end{array}$} & \multirow[t]{2}{*}{$\mathrm{CC}$} & \multirow[t]{2}{*}{97} & \multirow[t]{2}{*}{32} & \multirow{2}{*}{$\begin{array}{l}\text { Push enteroscopy } \\
\text { for: } 40 \% \text { OGIB, } \\
39 \% \text { overt bleed- } \\
\text { ing, } 12 \% \text { diar- } \\
\text { rhea, } 9 \% \text { mucosal } \\
\text { disease }\end{array}$} & \multirow[t]{2}{*}{ GIAD } & $\begin{array}{l}\text { Age } \\
40 \%>65 \text { years } \\
\text { versus } \\
12 \%<65 \text { years }\end{array}$ & $P<0.001$ \\
\hline & & & & & & $\begin{array}{l}\text { CKD } 54 \% \text { in } \\
\text { GIAD versus } \\
27 \% \text { control }\end{array}$ & $P<0.05$, OR 3.2 \\
\hline $\begin{array}{l}\text { Clouse et al. USA, } \\
1985 \text { [32] }\end{array}$ & $\mathrm{CC}$ & 90 & 30 & $\begin{array}{l}\text { EGD for suspected } \\
\text { upper GI bleed- } \\
\text { ing }\end{array}$ & GIAD & $\begin{array}{l}\text { CKD } 60 \% \text { in } \\
\text { GIAD versus } \\
24 \% \text { control }\end{array}$ & $P<0.001$ OR 4.6 \\
\hline $\begin{array}{l}\text { Blackshear et al. } \\
\text { USA, } 2014 \text { [34] }\end{array}$ & $\mathrm{RC}$ & 46 & 7 & Endoscopy NS & $\begin{array}{l}\text { Mitral valve } \\
\text { regurgitation and } \\
\text { GIAD }\end{array}$ & $\begin{array}{l}13.2 \% \text { GIAD in pts } \\
\text { with mitral valve } \\
\text { regurgitation }\end{array}$ & NA \\
\hline $\begin{array}{l}\text { French et al. USA, } \\
2013 \text { [35] }\end{array}$ & $\mathrm{RC}$ & 31 & - & $\begin{array}{l}\text { EGD, colonoscopy } \\
\text { or push enteros- } \\
\text { copy for bleeding } \\
\text { event }\end{array}$ & LVAD and GIAD & $\begin{array}{l}\text { GIAD as cause in } \\
17.5 \% \text { of all GI } \\
\text { bleeding events } \\
\text { in LVAD }\end{array}$ & NA \\
\hline $\begin{array}{l}\text { Bhutani et al. USA, } \\
1995 \text { [38] }\end{array}$ & $\mathrm{PC}$ & 37 & 40 & $\begin{array}{l}\text { EGD or colonos- } \\
\text { copy for: polyps/ } \\
\text { cancer } 18 \%, \text { ane- } \\
\text { mia } 30 \%, \text { overt } \\
\text { bleeding } 35 \%, \\
\text { dyspepsia } 18 \%\end{array}$ & GIAD pts & $0 \%$ aortic stenosis & NA \\
\hline $\begin{array}{l}\text { Marcuard et al. } \\
\text { USA, } 1988 \text { [39] }\end{array}$ & Cohort & 32 & 15 & $\begin{array}{l}\text { Overt GI bleeding, } \\
\text { AGD or colonos- } \\
\text { copy }\end{array}$ & $\begin{array}{l}\text { GIAD in dialysis } \\
\text { pts }\end{array}$ & $\begin{array}{l}32 \% \text { of CKD pts } \\
\text { with GI bleeding } \\
\text { have GIAD }\end{array}$ & NA \\
\hline $\begin{array}{l}\text { Sotoudehmanesh } \\
\text { et al. Iran, } 2003 \\
\text { [36] }\end{array}$ & $\mathrm{PC}$ & 197 & 9 & $\begin{array}{l}\text { Routine EGD } \\
\text { before renal } \\
\text { transplant }\end{array}$ & $\begin{array}{l}\text { GIAD in dialysis } \\
\text { pts } \pm \text { GI bleeding }\end{array}$ & $\begin{array}{l}\text { Incidence in pre- } \\
\text { renal transplant } \\
\text { pts: } 4.4 \% \text { GIAD }\end{array}$ & NA \\
\hline
\end{tabular}

\section{Triggers for Angiodysplasia Causing Overt or Occult Bleeding}

Only two retrospective cohort studies assessed factors that trigger symptomatic disease defined as anemia or overt GI bleeding (Table 3) [40-42]. Both studies only include colon angiodysplasias. Independent risk factors identified by two studies for symptomatic disease were age above 80 years (OR 5.2 and 1.3) and multiple lesions (OR 6.7 and 2.2). The study by Diggs et al. [42] is a population-based study with a large sample size $(n=4159)$. Inpatient status had the largest effect size in this study with an OR of 8.7 (95\% CI 5.4-14.1). Nishiruma et al. [40] found heart disease in past medical history (OR 6.9, 95\% CI 1.0-45.5) and angiodysplasia lesions $\leq 5 \mathrm{~mm}$ (OR 17.7, 95\% CI 4.9-64.0) as risk factors with a large effect size.

\section{Predictors for Rebleeding and Mortality in Patients with Symptomatic Angiodysplasias}

Six retrospective cohort studies investigated factors associated with rebleeds in a population of symptomatic patients (Table 4) [12, 43-49]. Two studies assessed risk factors for mortality $[43,49]$. One scrutinized the natural history of GI bleeding in VWD [12]. Independent risk factors for rebleeding identified by at least two studies are multiple lesions (OR 4.2, 95\% CI 1.1-16.2 and 3.8, 95\% CI 1.3-11.3 and 8.6, 95\% CI 1.4-52.6) [46-48]. In addition, 
Table 2 Studies assessing risk factors for bleeding angiodysplasias compared to patients without gastrointestinal bleeding

\begin{tabular}{|c|c|c|c|c|c|c|c|}
\hline Author Country, year & $\begin{array}{l}\text { Study } \\
\text { type }\end{array}$ & $\begin{array}{l}\text { No. of pts } \\
\text { controls }\end{array}$ & $\begin{array}{l}\text { No. of } \\
\text { pts with } \\
\text { GIAD }\end{array}$ & Study population & Comparison group & Outcome & $\begin{array}{l}\text { Effect HR } \\
(95 \%-C I) / t \text { test }\end{array}$ \\
\hline \multirow{10}{*}{$\begin{array}{l}\text { Holleran et al. Ire- } \\
\text { land, } 2013 \text { [29] }\end{array}$} & \multirow[t]{10}{*}{$\mathrm{CC}$} & \multirow[t]{10}{*}{95} & \multirow[t]{10}{*}{66} & \multirow{10}{*}{$\begin{array}{l}\text { Small bowel GIAD at } \\
\text { SBCE/51\% anemia, } \\
23 \% \text { overt bleeding, } \\
15 \% \text { OGIB, } 11 \% \\
\text { other }\end{array}$} & \multirow{10}{*}{$\begin{array}{l}\text { No GI bleeding/ } \\
\text { determined by two } \\
\text { negative FOBT for } \\
\text { colorectal cancer } \\
\text { screening program }\end{array}$} & Hypertension & $2.8(1.5-5.4)$ \\
\hline & & & & & & Ischemic heart disease & $4.3(1.9-9.8)$ \\
\hline & & & & & & Arrhythmias & $4.4(1.7-11.2)$ \\
\hline & & & & & & Valvular heart disease & $\begin{array}{c}18.8(2.4- \\
149.6)\end{array}$ \\
\hline & & & & & & $\begin{array}{l}\text { Congestive cardiac } \\
\text { failure }\end{array}$ & $4.5(1.2-17.9)$ \\
\hline & & & & & & CKD & $4.5(1.9-10.5)$ \\
\hline & & & & & & Previous VTE & $6.4(1.3-31.3)$ \\
\hline & & & & & & Anticoagulant use $\mathrm{a}^{\mathrm{a}}$ & $2.7(1.4-5.1)$ \\
\hline & & & & & & Warfarin $^{\mathrm{a}}$ & $5.5(1.1-27.5)$ \\
\hline & & & & & & $\begin{array}{l}\text { Proton pump } \\
\text { inhibitor }^{\mathrm{a}}\end{array}$ & $5.4(2.7-10.7)$ \\
\hline \multirow{6}{*}{$\begin{array}{l}\text { Cochrane et al. USA, } \\
2016 \text { [33] }\end{array}$} & \multirow[t]{6}{*}{$\mathrm{CC}$} & \multirow[t]{6}{*}{56} & \multirow[t]{6}{*}{14} & \multirow{6}{*}{$\begin{array}{l}\text { LVAD and GIAD } \\
\text { diagnosed with EGD } \\
\text { or colonoscopy }\end{array}$} & \multirow{6}{*}{$\begin{array}{l}\text { LVAD without GI } \\
\text { bleeding }\end{array}$} & Age & $1.3(1.1-1.6)$ \\
\hline & & & & & & CKD & $21.0(2.5-181)$ \\
\hline & & & & & & $\begin{array}{l}\text { Length of stay after } \\
\text { LVAD }\end{array}$ & $5.1(1.1-23.7)$ \\
\hline & & & & & & Sex: male & $0.1(0.01-0.9)$ \\
\hline & & & & & & Diabetes mellitus & $0.9(0.01-0.6)$ \\
\hline & & & & & & Hypertension & $0.2(0.1-0.97)$ \\
\hline $\begin{array}{l}\text { Duchini et al. USA, } \\
1998 \text { [37] }\end{array}$ & $\mathrm{RC}$ & 135 & 9 & $\begin{array}{l}\text { SS/CREST and GIAD } \\
\text { bleeding/endoscopy } \\
\text { or radiology NS }\end{array}$ & $\begin{array}{l}\text { SS/CREST without } \\
\text { clinical signs of GI } \\
\text { bleeding }\end{array}$ & $\begin{array}{l}6.3 \% \text { have GI bleeding } \\
\text { due to GIAD }\end{array}$ & NA \\
\hline \multirow{2}{*}{$\begin{array}{l}\text { Kim et al. Korea, } \\
2016 \text { [41] }\end{array}$} & \multirow[t]{2}{*}{$\mathrm{RC}$} & \multirow[t]{2}{*}{35} & \multirow[t]{2}{*}{58} & \multirow{2}{*}{$\begin{array}{l}\text { UGIB due to GIAD, } \\
\text { diagnosed with EGD, } \\
\text { SBCE or colonoscopy }\end{array}$} & \multirow{2}{*}{$\begin{array}{l}\text { Asymptomatic health } \\
\text { screening }\end{array}$} & Size $A D \geq 1 \mathrm{~cm}$ & $-(1.04-15.9)$ \\
\hline & & & & & & Site: stomach & $-(1.2-12.5)$ \\
\hline
\end{tabular}

$C C$ case-control study, $R C$ retrospective cohort, $P C$ prospective cohort, GIAD gastrointestinal angiodysplasias, $O G I B$ occult gastrointestinal bleeding, $O R$ Odds ratio, VTE venous thromboembolism, LVAD's left ventricular assist devices, GI gastrointestinal, $C K D$ chronic kidney disease, NSAID nonsteroidal anti-inflammatory drugs, PPI proton pump inhibitor, yrs years, FOBT fecal occult blood test, pts patients, SBCE small bowel capsule endoscopy, EGD esophagogastroduodenoscopy, $N A$ not applicable, - missing

${ }^{a}$ Analysis: not reported univariate or multivariate analysis

liver cirrhosis (OR 4.0), location in the third small bowel quartile (OR 4.3), chronic kidney disease (4.5), congestive heart failure (4.5) and a prothrombin time $<30 \%$ (OR 4.2) were detected as bonafide risk factors with a moderate effect size. Prothrombin time was studied in the setting of acute GI bleeding [48]. Multiple $(\geq 3)$ comorbidities led to an increased risk (OR 2.3, 95\% CI 1.2-4.3) of in-hospital mortality and inpatient status to an increased 90-day mortality (OR 17.7, 95\% CI 1.7-185.1) in patients with angiodysplasias [49].

\section{Discussion}

This systematic review gives an overview of risk factors associated with detection of angiodysplasias during endoscopy, triggers for overt or occult bleeding and factors that contribute to rebleeds and mortality as a result of angiodysplasias. Age, chronic kidney disease, anticoagulant use and cardiovascular disease are the most important factors associated with the detection of angiodysplasias during endoscopy $[16,28,29]$. In view of the pathophysiological hypothesis, it is plausible that age, chronic kidney and cardiovascular disease contribute to development of angiodysplasias. Inpatient status is strongly associated with bleeding disease; however, this association with inpatient status is probably the consequence of the bleeding rather than an etiologic factor and thereby not clinically significant. Multiple lesions increase the risk of rebleeds.

The over-arching aim of this systematic review is to define factors that determine the presence of gastrointestinal angiodysplasias and/or affect the progression to symptomatic disease. The use of a risk stratification to guide management requires a thorough assessment of 
Table 3 Studies assessing triggers for overt or occult bleeding in patients with angiodysplasias

\begin{tabular}{|c|c|c|c|c|c|c|c|}
\hline \multirow{2}{*}{$\begin{array}{l}\text { Author Country, } \\
\text { year }\end{array}$} & \multirow[t]{2}{*}{ Study type } & \multirow{2}{*}{$\begin{array}{l}\text { No. of pts } \\
\text { sympto- } \\
\text { matic }\end{array}$} & \multirow{2}{*}{$\begin{array}{l}\text { No. of pts } \\
\text { asympto- } \\
\text { matic }\end{array}$} & \multirow{2}{*}{$\begin{array}{l}\text { Inclusion type of } \\
\text { GIAD }\end{array}$} & \multirow[t]{2}{*}{ Comparison group } & \multicolumn{2}{|l|}{ Outcomes } \\
\hline & & & & & & $\begin{array}{l}\text { Significant risk } \\
\text { factors multivariate } \\
\text { analysis }\end{array}$ & Effect OR $(95 \%-\mathrm{CI})$ \\
\hline $\begin{array}{l}\text { Nishimura et al. } \\
\text { Japan, } 2016 \text { [40] }\end{array}$ & $\mathrm{RC}$ & 29 & 406 & $\begin{array}{l}\text { Colon, active } \\
\text { bleeding during } \\
\text { endoscopy }\end{array}$ & $\begin{array}{l}\text { No active bleeding } \\
\text { GIAD during } \\
\text { colonoscopy }\end{array}$ & $\begin{array}{l}\text { Age }>80 \text { years } \\
\text { Heart disease } \\
\text { Anticoagulant use } \\
\text { Multiple lesions } \\
\text { AD lesions } \leq 5 \mathrm{~mm}\end{array}$ & $\begin{array}{l}5.15(1.61-16.5) \\
6.88(1.04-45.5) \\
4.22(1.21-14.7) \\
6.67(1.77-25.2) \\
17.7(4.90-64.0)\end{array}$ \\
\hline $\begin{array}{l}\text { Diggs et al. USA, } \\
2011 \text { [42] }\end{array}$ & $\mathrm{RC}$ & 2320 & 1839 & $\begin{array}{l}\text { Colon angiodys- } \\
\text { plasia with occult } \\
\text { or overt bleeding }\end{array}$ & $\begin{array}{l}\text { Colon angiodys- } \\
\text { plasia without } \\
\text { occult or overt } \\
\text { bleeding }\end{array}$ & $\begin{array}{l}\text { Inpatient status } \\
\text { Age }>80 \text { years } \\
\text { ASA class } \geq \text { III } \\
\text { Black race } \\
\text { Hispanic ethnicity } \\
2-10 \text { lesions } \\
>10 \text { lesions }\end{array}$ & $\begin{array}{l}8.74(5.4-14.1) \\
1.32(1.1-1.6) \\
1.97(1.6-2.4) \\
1.95(1.5-26.6) \\
1.71(1.3-2.2) \\
1.50(1.3-1.8) \\
2.18(1.7-2.8)\end{array}$ \\
\hline
\end{tabular}

$P C$ prospective cohort, $R C$ retrospective cohort, GI gastrointestinal, No number, GIAD angiodysplasia, pts patients, UGIB upper GI bleeding, $O R$ odds ratio, $C I$ confidence interval, ASA American Society of Anesthesiologists, - missing

the contribution of individual risk factors to the clinical picture. Patients who develop bleeding angiodysplasias and possess multiple risk factors that amplify the risk for rebleeding deserve close monitoring but also reassessment of those conditions that put the patient at a higher risk. For example, (over-) anticoagulation and valvular heart disease can be amended or treated. The efforts needed to lower the risk profile by treating underlying conditions can be complimentary to aggressive endoscopic treatment. Efforts to investigate the efficacy of different treatment strategies in low and high risk patients in order to fuel the evidence base are welcome.

At present, one of the major issues in clinical management of asymptomatic angiodysplasias is that evidence on treatment outcome is based on heterogeneous small and often non-controlled studies [18-22, 50-54]. This results in considerable practice variation [55]. More understanding of the different risk profiles of patients with different severity of the disease helps to make the right decision in whether to treat and which treatment modality would be needed.

This systematic review allows identification of gaps that helps in the management of this disease. It also illustrates the complexity and wide phenotypical range of disease severity. In comparison with other vascular malformations, such as GAVE, portal gastropathy and radiation-induced telangiectasias, the most prominent risk factors for the development of angiodysplasias and severity of the disease remain to be further investigated.

Our systematic review comes with inherent strengths and limitations. The strength of this study is that it includes a broad search strategy with a thoroughly performed quality assessment. Moreover, risk assessment based on confirmation of risk factors in a second study and those with a moderate effect size $(\mathrm{OR}>3.5)$ is performed. To get a clear overview, we subdivided the risk factors for different stages of disease, i.e., risk to detect angiodysplasias during endoscopy, angiodysplasias that cause overt bleeding or anemia and a more severe course with rebleeds or mortality. In addition, the risk factors for each different disease stage include Western and Asian studies, thereby increasing the external validity of this review. A limitation of the study is that a meta-analysis was not possible due to the methodological heterogeneity between the studies. Moreover, the majority of studies identifying risk factors for finding angiodysplasias during endoscopy use different control groups and indications for endoscopy or only focus on small bowel angiodysplasias. We excluded case reports and small case series which could have led to the exclusion of diseases which are rare that increase the risk of the presence of angiodyplasias, e.g., bone marrow transplantation. We excluded other vascular anomalies, which could have introduced bias due to the inaccuracy of correctly distinguishing angiodysplasias from other vascular lesions at video capsule endoscopy. 
Table 4 Patient characteristics predicting rebleeds and mortality in patients with symptomatic angiodysplasias

\begin{tabular}{|c|c|c|c|c|c|c|c|c|}
\hline \multirow{2}{*}{$\begin{array}{l}\text { Author Coun- } \\
\text { try, year }\end{array}$} & \multirow[t]{2}{*}{ Study type } & \multirow{2}{*}{$\begin{array}{l}\text { No. of } \\
\text { AD pts ana- } \\
\text { lyzed }\end{array}$} & \multirow{2}{*}{$\begin{array}{l}\text { No. of } \\
\text { pts with } \\
\text { rebleeds }\end{array}$} & \multirow{2}{*}{$\begin{array}{l}\text { Type/detection } \\
\text { of } \mathrm{AD}\end{array}$} & \multirow{2}{*}{$\begin{array}{l}\text { Follow-up: \% } \\
\text { and years }\end{array}$} & \multirow[t]{2}{*}{ Outcome } & \multicolumn{2}{|l|}{ Outcomes } \\
\hline & & & & & & & $\begin{array}{l}\text { Significant } \\
\text { risk factors } \\
\text { multivariate } \\
\text { analysis }\end{array}$ & $\begin{array}{l}\text { Effect OR/HR } \\
(95 \% \text {-CI) }\end{array}$ \\
\hline \multirow[t]{4}{*}{$\begin{array}{l}\text { Mai et al. USA, } \\
2017 \text { [43] }\end{array}$} & \multirow[t]{4}{*}{$\mathrm{RC}$} & \multirow[t]{4}{*}{87} & \multirow[t]{4}{*}{14} & \multirow[t]{4}{*}{$\begin{array}{l}\text { SBA, capsule } \\
\text { endoscopy }\end{array}$} & \multirow[t]{4}{*}{$\begin{array}{l}100 \% \text { at least } \\
1 \text { year }\end{array}$} & \multirow[t]{3}{*}{ Rebleeds } & $\begin{array}{l}\text { Non-isolated } \\
\text { GIAD }\end{array}$ & $4.2(1.1-16.2)$ \\
\hline & & & & & & & $\begin{array}{l}\text { Chronic kidney } \\
\text { disease }\end{array}$ & $4.5(1.0-19.6)$ \\
\hline & & & & & & & $\begin{array}{l}\text { Congestive } \\
\text { heart failure }\end{array}$ & $4.5(1.0-19.9)$ \\
\hline & & & & & & $\begin{array}{l}\text { 90-day mortal- } \\
\text { ity }\end{array}$ & Inpatients & $17.7(1.7-185.1)$ \\
\hline \multirow{3}{*}{$\begin{array}{l}\text { Kaufman et al. } \\
\text { USA, } 2016 \\
\text { [44] }\end{array}$} & \multirow[t]{3}{*}{$\mathrm{RC}$} & \multirow[t]{3}{*}{156} & \multirow[t]{3}{*}{46} & \multirow[t]{3}{*}{$\begin{array}{l}\text { SBA, capsule } \\
\text { endoscopy }\end{array}$} & \multirow[t]{3}{*}{-} & \multirow[t]{3}{*}{ Rebleeds } & $\begin{array}{l}\text { Age of diag- } \\
\text { nosis }\end{array}$ & $1.05(1.01-1.09)$ \\
\hline & & & & & & & $\begin{array}{l}\text { Active } \\
\text { bleeding } \\
\text { on capsule } \\
\text { endoscopy }\end{array}$ & $2.69(1.15-6.30)$ \\
\hline & & & & & & & $\begin{array}{l}\text { Location: } \\
\text { quartile } 3\end{array}$ & $\begin{array}{l}4.29(1.46- \\
12.56)\end{array}$ \\
\hline $\begin{array}{l}\text { Jeon et al. } \\
\text { Korea, } 2016 \\
{[45]}\end{array}$ & $\mathrm{RC}$ & 66 & 15 & $\begin{array}{l}\text { Balloon } \\
\text { assisted enter- } \\
\text { oscopy }\end{array}$ & $90 \%$, mean 1.8 & Rebleeds & Liver cirrhosis & $4.01(1.1-15.0)$ \\
\hline \multirow{2}{*}{$\begin{array}{l}\text { Holleran et al. } \\
\text { Ireland, } 2016 \\
\text { [46] }\end{array}$} & \multirow[t]{2}{*}{$\mathrm{RC}$} & \multirow[t]{2}{*}{56} & \multirow[t]{2}{*}{45} & \multirow[t]{2}{*}{$\begin{array}{l}\text { SBA, capsule } \\
\text { endoscopy }\end{array}$} & \multirow[t]{2}{*}{$65 \%$, mean 2.7} & \multirow[t]{2}{*}{ Rebleeds } & $\begin{array}{r}\text { Multiple } \\
\text { lesions }\end{array}$ & - \\
\hline & & & & & & & $\begin{array}{l}\text { Valvular heart } \\
\text { disease }\end{array}$ & - \\
\hline $\begin{array}{l}\text { Sakai et al. } \\
\text { Japan, } 2014 \\
\text { [47] }\end{array}$ & $\mathrm{RC}$ & 68 & 23 & $\begin{array}{l}\text { Capsule endos- } \\
\text { copy }\end{array}$ & $\begin{array}{l}92 \%, \text { median } \\
\quad 2.5\end{array}$ & Rebleeds & $\begin{array}{l}\geq 3 \text { angiodys- } \\
\text { plasias }\end{array}$ & $3.82(1.3-11.3)$ \\
\hline \multirow{2}{*}{$\begin{array}{l}\text { Saperas et al. } \\
\text { Spain, } 2009 \\
\text { [48] }\end{array}$} & \multirow[t]{2}{*}{$\mathrm{RC}$} & \multirow[t]{2}{*}{57} & \multirow[t]{2}{*}{17} & \multirow{2}{*}{$\begin{array}{l}\text { Acute GI } \\
\text { bleeding due } \\
\text { to GIAD, } \\
\text { endoscopy } \\
\text { NS }\end{array}$} & \multirow[t]{2}{*}{$92 \%$, mean 2.8} & \multirow[t]{2}{*}{ Rebleeds } & $\begin{array}{l}\text { Over-anticoag- } \\
\text { ulation }\end{array}$ & $4.15(1.1-15.4)$ \\
\hline & & & & & & & $\begin{array}{r}\text { Multiple } \\
\text { lesions }\end{array}$ & $8.63(1.4-52.6)$ \\
\hline $\begin{array}{l}\text { Makris et al. } \\
\text { UK, } 2015 \\
{[12]}\end{array}$ & $\mathrm{RC}$ & 48 & - & $\begin{array}{l}\text { Congenital } \\
\text { VWD with } \\
\text { GI bleeding, } \\
\text { diagnosed by } \\
\text { all types of } \\
\text { endoscopy/ } \\
\text { angiography/ } \\
\text { imaging } \\
\text { scans }\end{array}$ & - & $\begin{array}{l}37.5 \% \text { AD } \\
\text { cause of GI } \\
\text { bleeding }\end{array}$ & NA & NA \\
\hline $\begin{array}{l}\text { Serrao et al. } \\
\text { USA, } 2016 \\
\text { [49] }\end{array}$ & $\mathrm{RC}$ & 85971 & - & $\begin{array}{l}\text { GIAD by EGD, } \\
\text { ICD-codes }\end{array}$ & $\begin{array}{l}100 \%, \text { one } \\
\text { hospital } \\
\text { admission }\end{array}$ & $\begin{array}{r}\text { In-hospital } \\
\text { mortality }\end{array}$ & $\begin{array}{l}\geq 3 \text { comorbidi- } \\
\text { ties }\end{array}$ & $2.29(1.2-4.3)$ \\
\hline
\end{tabular}

$P C$ prospective cohort, $R C$ retrospective cohort, $O R$ odds ratio, $H R$ hazard ratio, $C I$ confidence interval, $S B A$ small bowel angiodysplasias, $G I A D$ gastrointestinal angiodysplasias, ICD international classification of diseases, NA not applicable, endoscopy NS type of endoscopy not specified, - missing

In conclusion, this systematic review identified important risk factors for angiodysplasias at different disease stages. The risk assessment identified age, chronic kidney disease and cardiovascular disease as the most important risk factors for the presence of angiodysplasias during endoscopy and multiple lesions contributing to disease severity. Information on these risk factors aids in accurate phenotyping which benefits clinical decision making. 


\section{Compliance with ethical standards}

Conflict of interest The authors declare that they have no conflict of interest.

Open Access This article is distributed under the terms of the Creative Commons Attribution-NonCommercial 4.0 International License (http://creativecommons.org/licenses/by-nc/4.0/), which permits any noncommercial use, distribution, and reproduction in any medium, provided you give appropriate credit to the original author(s) and the source, provide a link to the Creative Commons license, and indicate if changes were made.

\section{References}

1. Raju GS, Gerson L, Das A, Lewis B, American Gastroenterological Association. American Gastroenterological Association (AGA) Institute technical review on obscure gastrointestinal bleeding. Gastroenterology. 2007;133:1697-1717.

2. Costello SP, Martin J. Angioectasia in the elderly is the commonest cause of obscure gastrointestinal bleeding on capsule endoscopy. Gastrointest Endosc. 2012;75:AB260.

3. Sami SS, Al-Araji SA, Ragunath K. Review article: gastrointestinal angiodysplasia - pathogenesis, diagnosis and management. Aliment Pharmacol Ther. 2014;39:15-34.

4. Junquera F, Saperas E, de Torres I, et al. Increased expression of angiogenic factors in human colonic angiodysplasia. Am J Gastroenterol. 1999;94:1070-1076.

5. Holleran G, Hall B, O'Regan M, et al. Expression of angiogenic factors in patients with sporadic small bowel angiodysplasia. $J$ Clin Gastroenterol. 2015;49:831-836.

6. Kurosaki M, Saegert W, Abe T, et al. Expression of vascular endothelial growth factor in growth hormone-secreting pituitary adenomas: special reference to the octreotide treatment. Neurol Res. 2008;30:518-522.

7. Gjeorgjievski M, Cappell MS. Portal hypertensive gastropathy: a systematic review of the pathophysiology, clinical presentation, natural history and therapy. World J Hepatol. 2016;8:231-262.

8. Shepherd NA. Pathological mimics of chronic inflammatory bowel disease. J Clin Pathol. 1991;44:726.

9. Lee YT, Walmsley RS, Leong RW, et al. Dieaulafoy's lesion. Gastrointest Endosc. 2003;58:236.

10. Gordon FH, Watkinson A, Hodgson H. Vascular malformations of the gastrointestinal tract. Best Pract Res Clin Gastroenterol. 2001;15:41-58.

11. Gunnlaugsson O. Angiodysplasia of the stomach and duodenum. Gastrointest Endosc. 1985;31:251-254.

12. Makris M, Federici AB, Mannucci PM, et al. The natural history of occult or angiodysplastic gastrointestinal bleeding in von Willebrand disease. Haemophilia. 2015;21:338-342.

13. Blackshear JL, McRee CW, Safford RE, et al. von Willebrand factor abnormalities and Heyde syndrome in dysfunctional heart valve prostheses. JAMA Cardiol. 2016;1:198-204.

14. Zuckerman GR, Cornette GL, Clouse RE, et al. Upper gastrointestinal bleeding in patients with chronic renal failure. Ann Intern Med. 1985;102:588.

15. Van Eysden P, Mevius L, Zaat J. Colorectal cancer screening program: one year after it's initation. Ned Tijdschr Geneeskd. 2015;159:A8844.

16. Lanas A, García-Rodríguez LA, Polo-Tomás M, et al. The changing face of hospitalisation due to gastrointestinal bleeding and perforation. Aliment Pharm Therap. 2011;33:585-591.
17. Cappell MS, Gupta A. A changing epidemiology of gastrointestinal angiodysplasia with increasing recognition of clinically milder cases: angiodysplasia tend to produce mild chronic gastrointestinal bleeding in a study of 47 consecutive patients admittedfrom1980-1989. Am J Gastroenterol. 1992;87:201-206.

18. Holleran G, Hall B, Breslin N, et al. Long-acting somatostatin analogues provide significant beneficial effect in patients with refractory small bowel angiodysplasia: results from a proof of concept open label mono-centre trial. United Eur Gastroenterol J. 2016;4:70-76.

19. Salgueiroa P, Marcos-Pintoa R, Liberald R, et al. Octreotide long-acting release is effective in preventing gastrointestinal bleeding due to angiodysplasias. GE Port J Gastroenterol. 2014;21:176-183.

20. Nardone G, Rocco A, Balzano T, et al. The efficacy of octreotide therapy in chronic bleeding due to vascular abnormalities of the gastrointestinal tract. Aliment Pharmacol Ther. 1999;13:1429-1436.

21. Bon C, Aparicio T, Vincent M, et al. Long-acting somatostatin analogues decrease blood transfusion requirements in patients with refractory gastrointestinal bleeding associated with angiodysplasia. Aliment Pharmacol Ther. 2012;36:587-593.

22. Scaglione G, Pietrini L, Russo F, et al. Long-acting octreotide as rescue therapy in chronic bleeding from gastrointestinal angiodysplasia. Aliment Pharmacol Ther. 2007;26:935-942.

23. Junquera F, Saperas E, Videla S, et al. Long-term efficacy of octreotide in the prevention of recurrent bleeding from gastrointestinal angiodysplasia. Am J Gastroenterol. 2007;102:254-260.

24. Moher D, Liberati A, Tetzlaff J, Altman DG, The PRISMA Group. Preferred reporting items for systematic reviews and meta-analyses: The PRISMA statement. BMJ. 2009;339:b2535.

25. Wells GA, Shea B, O'Connell D et al. The Newcastle-Ottawa Scale (NOS) for assessing the quality if nonrandomized studies in meta-analyses. Available from: http://www.ohri.ca/programs/ clinical_epidemiology/oxford.htm;2009 [cited 2016 Oct 12].

26. Lakens D. Calculating and reporting effect sizes to facilitate cumulative science: a practical primer for $t$-tests and ANOVAs. Front Psychol. 2013;4:863.

27. Chen H, Cohen P, Chen S. How big is a big odds ratio? Interpreting the magnitudes of odds ratios in epidemiological studies. Commun Stat Simul Comput. 2010;39:860-864.

28. Igawa $\mathrm{A}$, Oka $\mathrm{S}$, Tanaka S, et al. Major predictors and management of small-bowel angioectasia. BMC Gastroenterol. 2015;25:108.

29. Holleran G, Hall B, Hussey M, et al. Small bowel angiodysplasia and novel disease associations: a cohort study. Scand J Gastroenterol. 2013;48:433-438.

30. Macdonald J, Porter V, Scott NW, et al. Small bowel lymphangiectasia and angiodysplasia: a positive association; novel clinical marker or shared pathophysiology? J Clin Gastroenterol. 2010;44:610-614.

31. Chak A, Koehler MK, Sundaram SN, et al. Diagnostic and therapeutic impact of push enteroscopy: analysis of factors associated with positive findings. Gastrointest Endosc. 1998;47:18-22.

32. Clouse RE, Costigan DJ, Mills BA, et al. Angiodysplasia as a cause of upper gastrointestinal bleeding. Arch Intern Med. 1985;145:458-461.

33. Cochrane J, Jackson C, Schlepp G, et al. Gastrointestinal angiodysplasia is associated with significant gastrointestinal bleeding in patients with continuous left ventricular assist devices. Endosc Int Open. 2016;4:E371-E377.

34. Blackshear JL, Wysokinska EM, Safford RE, et al. Shear stressassociated acquired von Willebrand syndrome in patients with mitral regurgitation. J Thromb Haemost. 2014;12:1966-1974. 
35. French JB, Pamboukian SV, George JF, et al. Gastrointestinal bleeding in patients with ventricular assist devices is highest immediately after implantation. ASAIO J. 2013;59:480-485.

36. Sotoudehmanesh R, Ali Asgari A, Ansari R, et al. Endoscopic findings in end-stage renal disease. Endoscopy. 2003;35:502-505.

37. Duchini A, Sessoms SL. Gastrointestinal hemorrhage in patients with systemic sclerosis and CREST syndrome. Am J Gastroenterol. 1998;93:1453-1456.

38. Bhutani MS, Gupta SC, Markert RJ, et al. A prospective controlled evaluation of endoscopic detection of angiodysplasia and its association with aortic valve disease. Gastrointest Endosc. 1995;42:398-402.

39. Marcuard SP, Weinstock JV. Gastrointestinal angiodysplasia in renal failure. J Clin Gastroenterol. 1988;10:482-484.

40. Nishimura N, Mizuno M, Shimodate Y, et al. Risk factors for active bleeding from colonic angiodysplasia confirmed by colonoscopic observation. Int J Colorectal Dis. 2016;31:1869-1873.

41. Kim DB, Chung WC, Lee SJ, et al. Analysis of risk factor and clinical characteristics of angiodysplasia presenting as upper gastrointestinal bleeding. Korean J Intern Med. 2016;31:669-677.

42. Diggs NG, Holub JL, Lieberman DA, et al. Factors that contribute to blood loss in patients with colonic angiodysplasia from a population-based study. Clin Gastroenterol Hepatol.. 2011;9:415-420. (quiz e49).

43. Mai SH, Chao DC, Liao S, Jackson CS. Nonisolated small bowel gastrointestinal angiodysplasias are associated with higher rebleeding rated when compared with isolated small bowel gastrointestinal angiodysplasia on video capsule endoscopy. J Clin Gastroenterol. 2018;52:726-733.

44. Kaufman D, Leslie G, Marya N, et al. Small intestinal angioectasia: characterization, risk factors, and rebleeding. J Clin Gastroenterol. 2017;51:720-727.

45. Jeon SR, Byeon JS, Jang HJ et al. Clinical outcome after enteroscopy for small bowel angioectasia bleeding: a kasid multicenter study. J Gastroenterol Hepatol. 2017;32:388-394.

46. Holleran G, Hall B, Zgaga L, et al. The natural history of small bowel angiodysplasia. Scand J Gastroenterol. 2016;51:393-399.
47. Sakai E, Endo H, Taguri M, et al. Frequency and risk factors for rebleeding events in patients with small bowel angioectasia. $B M C$ Gastroenterol. 2014;28:200.

48. Saperas E, Videla S, Dot J, et al. Risk factors for recurrence of acute gastrointestinal bleeding from angiodysplasia. Eur J Gastroenterol Hepatol. 2009;21:1333-1339.

49. Serrao S, Jackson C, Juma D, et al. In-hospital weekend outcomes in patients diagnosed with bleeding gastroduodenal angiodysplasia: a population-based study, 2000 to 2011. Gastrointest Endosc. 2016;84:416-423.

50. Godeschalk MF, Mensink PB, van Buuren HR, et al. Primary balloon-assisted enteroscopy in patients with obscure gastrointestinal bleeding: findings and outcome of therapy. J Clin Gastroenterol. 2010;44:e195-e200.

51. Jarbandhan S, van der Veer WM, Mulder CJ. Double-balloon endoscopy in the diagnosis and treatment of hemorrhage from retrovalvular angiodysplasias. J Gastrointestin Liver Dis. 2008; 17:333-334.

52. Sun B, Rajan E, Cheng S, et al. Diagnostic yield and therapeutic impact of double-balloon enteroscopy in a large cohort of patients with obscure gastrointestinal bleeding. Am J Gastroenterol. 2006;101:2011-2015.

53. Monkemuller K, Weigt J, Treiber G, et al. Diagnostic and therapeutic impact of double-balloon enteroscopy. Endoscopy. 2006;38:67-72.

54. Eickhoff A, Enderle MD, Hartmann D, et al. Effectiveness and Safety of PRECISE APC for the treatment of bleeding gastrointestinal angiodysplasia - a retrospective evaluation. $Z$ Gastroenterol. 2011;49:195-200.

55. Grooteman KV, van Geenen EJ, Drenth JP. High variation in treatment strategies for gastrointestinal angiodysplasias. Eur J Gastroenterol Hepatol. 2016;28:1082-1086.

Publisher's Note Springer Nature remains neutral with regard to jurisdictional claims in published maps and institutional affiliations. 